This is an Accepted Manuscript of an article published by Taylor \& Francis Group in Environmental Communication on 11/07/2018, available online:

http://www.tandfonline.com/10.1080/17524032.2018.1482835

\title{
Nature Articulations in Norwegian Advertising Discourse: A Depoliticized Discourse of Climate Change
}

\author{
Journal name: Environmental Communication
}

\section{Trine Kvidal-Røvik}

Department of Tourism and Northern Studies, UiT The Arctic University of Norway, Alta, Norway

Trine Kvidal-Røvik, Associate Professor, Department of Tourism and Northern Studies, UiT The Arctic University of Norway, Follumsvei 31, N-9509 Alta, Norway, trine.kvidal@uit.no, $+4797985624$

\begin{abstract}
This article deals with how nature is articulated in public discourse, and more specifically how humans' relationship to nature is constructed via such articulations. Based on critical cultural analyses of ads presented in a Norwegian context, the article claims articulations of nature serve to a depoliticization of nature, which silence social differences and reduce environmental politics to individual moral action. Several rhetorical patterns of particular relevance to the articulation of nature are discussed, pointing out how disparate, sometimes conflicting, understandings of nature are rhetorically configured and aligned in ways that benefit a global market economy. There is a discursive distancing of nature and everyday life, even as nature remains valorized and very much central to national identity. This constrains citizens' political engagement and undermines understandings of how to govern nature.
\end{abstract}

Key words: Nature, Articulation, Climate change, Depoliticization, Advertising, Norway

\section{Introduction}

In this article, I am interested in how humans' relationship to nature is constructed via articulations in public discourse. Taking Norway as an entry point, I build knowledge on how nature understandings become articulated in a specific cultural and political context and I show how such constructions of nature are relevant for understandings of climate change. 
Climate change has increasingly become an important part of the environmental debate in Norway since the early 2000s (Aasen, 2017). Using critical cultural literature on cultural values as a guide, I engage in a critical analysis of advertisements presented to Norwegian audiences. As a northern country, Norway represents an early warning of climate-related problems or, as Chapin III et al. (2004, p. 348) say, a canary in the mineshaft of global change-one of the first places where climate warming has clear effects. Norway is also a particularly relevant case as nature represents a potent site of tension for the country due to a strong symbolic position of nature culturally and politically, combined with nature's central role in the nation's economy, for instance extensive oil industry, fish farming activities, and, in recent years, a growing awareness of nature as a resource in tourism.

I see commercial texts as particularly useful for research on nature articulations, because of how such articulations capture public discourses and social imaginaries, especially as relevant to cultural identity(ies). How we articulate nature plays a role in structuring knowledge and social practices of relevance to policies dealing with climate change. In line with such a conceptualization, this analysis discusses how nature is articulated in ads circulating in a Norwegian context, and what erasures this enacts, i.e., how nature is made relevant through the very means of its representation. I discuss four rhetorical patterns of particular relevance to the articulation of nature in the advertising discourse: deification, commodification, domination and internalization. I claim there is a distancing and individualizing of the human relationship to nature. This is relevant in terms of climate change since people holding less individualistic values are more concerned about climate change than those holding individualistic values (Aasen, 2017), and I suggest this is part of a depoliticization of nature in Norway, which in turn undermines the political engagement needed for good discussions regarding global challenges such as climate change. 


\section{Discursive Articulations of Nature}

Pointing out that understandings of nature are socially, politically and culturally constructed is not new (i.e. Corbett, 2006; Cox, 2012; Hansen, 2010; Hansen \& Machin, 2013; Macnaghten \& Urry, 1998); in fact, Raymond Williams established nature as a cultural concept already in the 70s, when he claimed nature was "the most complex word in the language" (1983, p. 219). Mediated communication about nature is central to what we know about the environment, as it represents "a central public arena through which we become aware of environmental issues and the way in which they are addressed, contested and resolved" (Hansen, 2011, p. 9).

Scholars claim beliefs and knowledge on environmental issues extends to the ways we as individuals, citizens, cultures and societies view, perceive and value nature and the natural environment (Hansen, 2010) and matters in terms of the choices we make in response to environmentally related problems (Cox, 2012). In line with this, numerous researchers have discussed debates on climate change in public discourse (i.e. Doyle, 2013; Gkiouzepas \& Botetzagias, 2015; Maeseele \& Pepermans, 2017; Maeseele, Raeijmaekers, Van der Steen, Reul, \& Paulussen, 2017; Pepermans \& Maeseele, 2014; Schmidt, Ivanova, \& Schäfer, 2013; Stoddart, Tindall, Smith, \& Haluza-Delay, 2017; Swyngedouw, 2011, 2013), yet there is a call for scholarship that brings forth knowledge on local meanings of climate and their relationship to human institutions and behavior more broadly (Pearce et al., 2017), more directly dealing with the wider circulation of politicizing discourses and how citizens at large may engage politically (Carvalho, van Wessel, \& Maeseele, 2017). Ideology, which binds and justifies social groups' ideas (Hall, 1995), is important to how we perceive and value nature and the natural environment around us and is important in the study of climate change communication because of how it naturalizes a particular historical cultural articulation of nature - "fixing" it, so to speak. In an overview of climate change communication, Maeseele and Pepermans (2017) underscore how the hegemony of a particular group or discourse is 
consolidated through depolitization, in which the discourse of climate change is presented as innocent of power and ideology, and environmental politics is reduced to individual moral action and/or technological innovation (Maeseele et al., 2017). Despite this, the role of ideology in media representations of nature and the environment is under-researched (Carvalho et al., 2017) and some say that the successes or failures of particular claims, frames and messages about environmental issues have to be understood "against the background of the kind of messages, images and ideologies about the environment that dominate and resonate in the wider cultural and symbolic environment" (Hansen, 2011, p. 13). With this in mind, I seek to contribute with knowledge on how nature is articulated in public discourse more specifically how humans' relationship to nature is constructed via such articulations.

My approach to articulations of nature is in line with critical cultural traditions, in particular in terms of discursive representations. Contemporary critical theory can be traced back to the Frankfurt School's theories on ideology as a mean to dominate the masses. This view of ideology has since become nuanced within contemporary critical cultural scholarship, which is heavily influenced by poststructuralist writings. In line with this, discourses are seen as systems of representation that fuses language and practice - "the state of knowledge" on a certain topic, including nature, at any one time (Foucault, 1996), which influence how we understand and make the world around us meaningful (Hall, 1997a). That is, while ideas and thoughts about nature may be very personal, such ideas and thoughts are always shaped within specific contexts, in which social, cultural, and economic dimensions play a role. This does not mean that our thoughts and ideas are determined by such dimensions, but rather that our knowledge and our social practices are structured through discourse.

In analyzing discourse in line with a critical cultural approach, the concept of articulations is particularly useful. Articulations are moments of arbitrary closure - forms of social 
constructions within a specific context (Laclau \& Mouffe, 1985, 1990). They are connections of different discursive elements that make a unity under certain conditions, bound by power of custom and opinion (Hall, 1995, 1997b; Slack, 1996). Using the concept of articulation of nature is valuable in that it resists a notion of absolute fixity. In line with this approach, nature is not a given, rather is created through articulations. As Swyngedouw (2011) says: "the natures we see and work with are imagined, scripted, and symbolically charged as Nature" (p. 261) and meanings are entangled with other meanings, as they are "quilting points through which a certain matrix of meanings of Nature is articulated“ (p. 257). By examining articulations that inform specific issues, like climate change, critics can reveal how meanings associated with an issue become naturalized.

In discussing articulations of nature, I look to mediated texts that circulate in public discourse. Mediated texts have an impact on how we see the world, and help shape our experience, relationships, interactions, understandings, and knowledge, hence influencing political debates and decision making (Allern, 2001; Neuman, Just, \& Crigler, 1992). I find ads particularly interesting, since, to use a small but telling quote from John Berger's Ways of Seeing (1972), advertising "is about social relations, not objects" (p. 132). Ads are discursive tools which express consumers' desires, hopes, and needs, while also being tightly connected to a hegemonic culture of consumption (Jameson, 1998; Ott \& Walter, 2000), and as such have more to do with image and ideology than information about products. By investigating ads, we can get at "the larger cultural, political and economic undercurrents of a given time and place" (Serazio \& Szarek, 2012, p. 754) - we can understand our society in new ways (R. Williams, 1993, p. 422). This means that advertising discourses related to nature, for instance, are of relevance to understanding the structuring knowledge and social practices connected to the environment. 
Several scholars have analyzed representations of nature and articulations of environmental issues in advertising and marketing (Corbett, 2006; Derrien \& Stokowski, 2017; Hope, 2002), pointing to, for instance, how nature is used in such texts in ways that construct and contribute to "boundaries and definitions of appropriate consumption and 'uses' of the natural environment" (Hansen, 2011, p. 11). Research also shows how nature is often used as a backdrop in advertising, presenting it for example as something to be controlled, as purity, as escape from the contemporary social and technological world, and as Utopian ideal (for an overview, see Rogers, 2008).

\section{Look(ing) to Norway}

Historically, nature has been a central aspect of Norwegian cultural identity and a powerful national symbol (Abram \& Lien, 2011; Gullestad, 1991a; Hylland Eriksen, 1993, 1996; Rybråten, 2013; Sørenssen, 2001; Vespestad, 2010; Ween \& Abram, 2012; Wiborg, 2003; Witoszek, 1998). Nature-nationalism, while not unique to Norway, has been pervasive and important across different fields such as art and music, but not least via outdoor activities such as hiking and skiing (Ween \& Abram, 2012). It is beyond the scope of this article to explain in detail how nature is constructed, performed and enacted in Norway, but it is important to know that in the Norwegian context (in contrast to most European countries), the rural 'home of nature' has been idealized over the urban (Halland, 1991; Hylland Eriksen, 1993) and the realm of nature has become associated with egalitarianism (Gullestad, 1991b), while public spheres (i.e. the state and the market) with hierarchy, formality, and impersonality (Lo, 2018; Sundsvold, 2010). As Sakslind and Skarpenes (2014) explains, during the Nordic Enlightenment in Norway, the peasants with their extraordinary peasant freedom and egalitarian codes, became a normative ideal and a connection of nature to selfless egalitarianism and humble living has been established via the role of the rural peasant life with/in nature (Ween \& Abram, 2012). 
Furthermore, natural resources have long played an important part in the Norwegian economy. Traditionally a considerable portion of the total labor force worked in the primary industries, and although these numbers have fallen to less than two percent today (Statistics Norway, 2017), natural resources are still important in Norway. Petroleum activities constitute the largest industry in terms of value, making up nearly 14\% of Norway's GDP, and even after the recent downturns in oil industry, the petroleum sector's share of total export revenues in Norway is $35 \%$ (Norway, 2017). Also, despite a relatively low number of people working in traditional fisheries or as fishers in Norway today, fish farming industry is very important economically. Norway is one of the largest fish farming nations globally and the value of fish and fish products constitute about $12 \%$ of the value of total exports in Norway (Norway, 2017). It is clear that with increased industrialization and urbanization, nature has taken on new purposes and roles (Cruickshank, 2009); it has become a commodity and a point of conjuncture between Norwegian and international partners in trade (D. Williams, 2001). Science, industrialization, and economics have played a crucial role in framing nature this way, and globalizing forces aggravates this by allowing ideologies of exploitation of nature. Importantly, the spread of a "free-market democracy" rests on the premise of "nature as a resource, or raw material, separate from human civilization, as well as a willingness to exploit nature in the betterment of human society" (Geisinger, 1999, p. 44). Nature, in this landscape, is not only seen as something separate from, and in opposition to, modern life (Macnaghten \& Urry, 1998), but also as something to be dominated and managed by people to the end of facilitating modern life (Bookchin, 2003).

\section{Methodological approach}

This article's methodological approach is informed by cultural studies and critical rhetoric.

Cultural studies generally focus on examining media's cultural ideological influence, and thus represents a valuable foundation for understanding processes of articulation (which are highly 
dependent on media). A critical rhetorical perspective complements this foundation as it attends to the ways in which power is culturally produced and circulated.

In order to discuss articulations of nature in the Norwegian context, I looked to ads that were aired by the Norwegian television broadcaster TV2 from 2004 to 2016. I began monitoring ads on TV2 (during prime time) in the summer of 2004, continuing through the summers of 2005, 2006, 2007 and 2008. In the first few years (2004-2008), I used videotaping to capture ads. During this period, I taped 1300 commercials. After a process where I excluded ads that had been recorded several times, as well as very short ads (e.g., a season-special on garden furniture, or other ads mainly presenting a still picture and information on a single item' price), I narrowed it down to 129 commercials from this first part of my research period. During to technological changes during the research period, the taping technology became outdated. I then used digital cable recordings, however the recording set-up was linked to regular programs and I was not guaranteed to capture ads aired in between programs. In the continuation of the research period, I thus changed my approach slightly. Using an ethnographically inspired approach, I observed ads aired during prime time, taking field notes, and then followed up particular ads via the internet afterwards (YouTube, or product/company/brand Web and/or Facebook pages). I systematically observed ads during prime time a few days every month with a few exceptions. I followed up 50 ads during this second part of the research period, ending up with a material of 179 ads that I examined in more depth.

Importantly, my discussion of nature articulations in the advertising discourse must not be seen as a comprehensive and systematic mapping of the advertising discourse's content in this time period, but an analytical engagement with the discursive site of televised ads aired (with)in a certain context, as particular histories and political geographies must be considered 
in understanding how cultural texts work. For this particular project, I surveyed the commercials with an eye toward whether they appeared to strongly feature elements that tied into articulation of nature. In preparation for this part, I conducted extensive literature research to develop an understanding of the knowledge situation (Haavind, 2000) related to nature in Norwegian cultural identity. This provided me with an understanding of key aspects of nature in Norwegian cultural identity as it has been conceptualized by previous scholars (i.e., Gullestad, 1989, 1991a, 1991b, 2002; Halland, 1991; Hylland Eriksen, 1993, 2005; Neumann, 2001; Skår \& Krogh, 2010; Sørenssen, 2001; Witoszek, 1998). In short, these researchers point out that key aspects of nature in an imagined Norwegian identity are notions of egalitarian equality and morality, intertwined with down-to-earth, quiet rural settings. Working with the ad material, I followed analytical conventions of rhetorical criticism and semiotics as informed by a critical rhetorical lens. Specifically, I surveyed the material with an eye toward how symbols (for instance images, words, dialects, sounds, musical elements) of nature were at play - their use and activation in the discourse, as well as underlying logics, intertextual references, visual or verbal associations and attributions present in each ad. I coded ads with regard to themes, values, patterns, and narrative elements to see how nature was articulated, and how humans' relationship to nature was presented. Also, keeping in mind discussions on depolitization, I looked for whether nature was articulated as a matter of political concern.

\section{Nature Articulated Along Four Rhetorical Patterns}

Based on my analysis, I found four rhetorical patterns of particular relevance to the articulation of nature: deification, appropriation, domination, and internalization. In the following, I will go into each of these in more detail. 


\section{Deification: Articulating a Sacred Nature}

The first way I see nature articulated is through deification, which means that nature is symbolically lifted up from regular life and repositioned as something to admire from below and from afar becoming separate, cordoned off, from everyday "normal" life. It is a strong pattern which I find throughout the research period. This happens in many ads where aspects of landscape - mountains, lakes, and fjords - are present. Mountains are generally presented as steep, dark, and snow-capped, accompanied by other cues, such as uplifting or spiritual music and crisp, clear, halo-like lighting, which frame these elements of nature as pure and sacred. Mountains are often presented in conjuncture with a "typical" Norwegian fjord or lake that is generally calm and glittering; often reflecting the sunlight as well as the adjacent mountains plunging into it. Power lines, modern buildings, structures, or roads are seldom visible (as they usually would be on most hikes in Norway). Apart from the occasional voiceover promoting a product or service, human presence is non-existent in these scenarios, reinforcing a sense of removed divinity. The nature offered in these ads, then, is far from regular life - as if from a distance in time or space and it certainly is an image of nature far from the urban life many Norwegians live.

A commercial for Suzuki cars is an example of such ads. It starts out with the image of a "traditional" fjord; viewers are met with steep, partially snow-covered mountains, which create the frame for sparkling fjord water on which two boats slowly float. The landscape is shown free from people. A hollow hoot from one of the boats blends in with the sound of screaming seagulls, completing the idyllic scene, before a fast-moving car is shown speeding up the well-known road "Trollstigen." The majestic scenery and lack of human presence presents nature as pristine, divine, and holy, set apart from "regular" human life, which is conversely presented as, if exuberantly so, chaos, noise, and artifice. The use of remote natural scenery provides a visual connection to a place beyond humans. This "use" of nature 
seems to represent a conceptualization of nature as something that is not only distanced, but, more importantly, also something mystical and different from regular life. The lack of material indications of modern life reinforces a sense of nature as uninhabited, remote, and beyond the human, making nature something to look up to - a larger, divine force. The divine aura created via editing, framing, and audio surrounds these aspects of nature, creating an elevation of nature - holding it up for everyone to see as something higher than - larger than - the individual Norwegian consumer, something above, far away, timeless.

As part of this deification of nature, a specific and powerful motif falls along the lines of salvation in relation to everyday urban life. That is, the urban setting is articulated as a source for discomfort (something to seek healing from), while nature is offered as salvation; the urban serves as an irreconcilable contrast to the divine nature, with sacred powers to heal. Two commercials for the beverage Meierienes Juice exemplify this healing. In both these texts, the main characters are shown drinking the advertised product while standing in urban settings. The commercials then show how they experience a form of relief when they drink Meierienes Juice; the traffic noise apparent at the beginning of the commercial literally disappears as the main characters in these ads enjoy their drink. As they consume the drink (represented visually by pieces of fruit), divine nature overpowers the urban setting; the main characters close their eyes as they "drink nature," displaying the pleasure gained from it. Urban-related worries are redressed via the consumption of nature - and this temporary respite is sufficient, there is no apparent need (nor is it presented as realistic) to escape permanently.

Symbolically, the texts that represent this pattern, pull people away from nature as deification necessitates marginalization and separation, but nature is not only divine and thus separate from humans in these texts; it is also something though which humans can imagine receiving 
healing from everyday problems and discomforts. Importantly, the imagined healing of culturally inflicted troubles, specifically problems associated with urbanness, comes in the form of symbolic salvation via products or services and thus reinforces a continued need for consumption and the commodification of nature. The concept of deification implies a notion of separation by superiority. The sentiment of nature as healer becomes part of re-defining and distancing nature.

\section{Appropriation: Commodifying Nature}

The second pattern I see relevant to the articulation of nature is appropriation. This means that nature is commodified and appropriated to make products more desirable. Nature is also exoticized and "othered," but can be purchased and consumed piece by piece as desired. This objectification of nature specifically happens in commercials endorsing certain types of food or beverages. Products are promoted as having the "flavor" of nature and the commercials suggest that nature can be "sampled" by eating and drinking these products. Like deification, it is a pattern I see relatively consistently throughout my research.

This can for example be seen in an ad for the beverage Bonaqua. Initially, the commercial's visual form seems like a spoof on James Bond-like action movies with a quick zoom-in on a high-tech "taste center" to the sounds of computer processing-like beeps and music. A view of the inside of this center shows a group of researchers in the process of perfecting the Bonaqua natural mineral water. Then, in stark contrast to this sterile environment, imagery of a remote lake fills the screen. One of the researchers stands on a rock on the side of the lake holding up a bottle of "Bonaqua." The background shows, in addition to a glittering mountain lake, two large partially snow-covered mountains. Aside from the researchers, no humans are present, reinforcing the qualitative distance between nature and "reality." The lower right corner of the screen then provides viewers with verbal information about the depicted place "Location Telemark" - indicating that the Bonaqua water (which is produced by the Coca 
Cola Company) is extracted from, or at least tastes like it was extracted from, this exact place, which is a Norwegian area with strong national connotations. ${ }^{i}$ The commercial, then, presents Norwegian lake water desirable as the ultimate thirst-quencher and pleasure-provider.

Interestingly, the Bonaqua taste person is transported between the edge of the remote Telemark lake and the inside of the test center in a magic fragmentation process. This mysterious way of moving from one place to another suggests that this is about more than a physical act of transportation. The intermediary technology presented in the ad seems to bring the main character between the ideal and ethereal place where Bonaqua comes from and the "real" world of scientific testing. In fact, viewers are able to observe that the lake still looks remote and unpopulated despite the presumed ongoing harvesting and tapping Telemark lake water on Bonaqua bottles. The magic displayed in this ad, then, allows for an imagined harmony between nature and development, between protecting natural resources and make the most (money) of nature. Viewers can imagine nature as pristine and separate from human "pollution" at the very same time as they can access the image of nature by putting the Bonaqua bottle to their mouth.

In commercials where nature is appropriated, nature is articulated as something divine and separate - something to long for, and to get access to, via consumption. Reduced to a sellable flavor, literally consumable via specific products, nature is something which provides pleasure and self-gratification to the individual consumer, but on a broader level this underscores the notion that nature in its entirety is inaccessible. Although pieces of nature can be extrapolated and consumed, nature in its entirety remains mystical, removed, and inaccessible. Nature is objectified and commodified in the very act of being represented as something pure, clean, and remote. Consumers, then, are presented with the opportunity to 
have an imaginary one on one relationship with nature via a specific product, which is conveniently available in the nearest grocery store.

\section{Domination: Articulating Nature as a Measurement of Power}

A third way that nature is positioned in the ads is along a theme of domination/control, which takes form in two ways: Patriarchal domination and paternal domination. First, patriarchal domination surfaces in texts where nature is shown as unruly or misbehaved in some way, and where the consumer is positioned as someone who should - and could - outsmart this disobedient nature. As relevant to this, a commercial for the paint Drygolin shows a small isolated house positioned next to the ocean. Rain and wind lashes out at the structure. The house seems to be at the mercy of the powerful forces of nature, and since, as the commercial's male voiceover says with pride, Norway can present "extremely bad weather" it is only this specific paint that will do. Via innovative and smart paint, then, the consumer can outsmart a wild and unruly Norwegian nature. A main character in the Drygolin commercial literally also outsmarts the extreme weather as he is "dressed for success," wearing a bright yellow sydvest, an outfit much associated with bad weather and being out on the open ocean in a small fish boat, and thus is able to get by.

With the strategy of patriarchical power, the separation from nature is maintained/reinforced, while an imaginary individual relationship is made available via products. That is, while the awesome quality of nature is presented as something to outwit and master via products available for purchase, the mystical quality of nature as something "out there," powerful, and unpredictable is retained. Via technologically superior products, the consumer can outsmart a wild and unruly nature. That Norwegians handle the tough weather nature cooks up, in this case by using "Drygolin" - says something about the Norwegian sentiment of being able to 
handle the weather. This pattern, while present throughout the research period, seems to appear less frequently than the patterns of deification and appropriation.

Second, a slightly different form of domination is related to the paternal, and this is a pattern that is not very visible at the beginning of the research period, but which seems to grow a little bit stronger toward the last part of my research period. An example of a paternal type of domination of nature is seen in a commercial for recycled materials - "Gjenvinning." This text, which promotes recycling of glass and plastic, presents two famous Norwegian male entertainers (Odd Børretzen and Ravi), traveling to a remote rural small store to recycle their bottles. As they put bottles into a recycling machine, a young blond woman working in the store smiles at them, clearly endorsing their care for the environment. The whole time, as they drive though green lush scenery after their visit with the smiling woman in the rural store, they sing a song about how "good it feels" to recycle. The commercial indicates that consumers can protect and guard the purity of nature through bringing in plastic and glass bottles. While this still implies a notion of nature as something outside of, separate from, everyday human life, the commercial provides viewers with a way to relate to nature through a paternal-like care. However, while this recycling might be a caring act, it is also a form of domination in that the remote nature is at the mercy of the consumer, which must be seen in the context of the globalized consumer culture of Norway. This imagined relationship reinforces the superfluousness of a "real" and everyday connection to nature. The strategy of paternal power (similarly to the previously discussed strategy of deification) ensures that nature is continuously cordoned off by paying homage through a symbolic admiration of distanced/distancing. Consumption of soda, then, does not threaten the environment, as long as we take the trip to the store to recycle our empty bottles. The consumer can choose to take care of nature on an individual basis, and increased consumption does not need to come at the 
expense of nature. This specific form of paternal domination becomes a way for Norwegian consumers to re-connect with nature.

With each of these configurations - patriarchical and paternal - nature is "othered," and presented as something to be dominated, handled, or managed, responsibly or cavalierly on an individual basis, and in this way, is symbolically separated in a similar fashion as with the strategy of deification.

\section{Internalizing Nature: Articulating Nature in/on the Body}

The last pattern I see has to do with nature in and on the body. This means that nature can live with/in people via an imagined internalization and a consumer-driven embeddedness; that is, nature can be read as being present on/in the Norwegian body.

In the advertising discourse, there is (not surprisingly) a presence of bodies representing a generic global definition of beauty, meaning a dominating conceptualization of beauty as connected to a thin, White, flawless body (Becker, 2004). These bodies are used to endorse many products, often included in the promotion of global brands and products, such as Axe, Lôreal, Elvital, and Vaseline Intensive Care, although more locally oriented brands such as Dressmann and Cubus also use such bodies when promoting their products. This global definition of beauty for the most part only dominates commercials that promote products associated with beauty and/or fashion. Here, the regular "natural" body, lacking all these elements, is seen as inadequate, insufficient, and inferior; it must be enhanced or remade with products. The global beauty body seems pervasive throughout the research period.

Importantly, there is also a distinctive Norwegian body present in the discourse - a body that almost seems to resist the perfect global look. This anti-glamour/anti-global body specifically aligns itself as a recalibration of the relationship between nature and Norwegian, via 
internalization. While this body may be as unrealistic as the flawless global body, it nevertheless presents consumers with something else to long for and strive for in their consumptive practices. This style of nature can be read specifically as two slightly different types of internalization: as ruggedness and as oddness. While these bodies are visible throughout the research period, they seem to appear less frequently toward the end of the period.

The rugged body is a tough and masculine individual. Typical for this specific body is a stoic calmness, even in the midst of a storm or a crisis in life. He (- and yes, this pattern only comes out in relation to male bodies) is like a Norwegian version of the American cowboy, a myth which foregrounds the idea of rugged individualism (Boşnak \& Ceyhan, 2003). An example of this specific body is represented in a Storebrand insurance commercial, where the Norwegian actor Espen Skjønberg is the main character. Skjønberg's age and experience, and the editing that positions him as powerful, underscore his credibility and by association boosts the credibility of the Storebrand services he endorses. His body and physical appearance, however, speak to a larger cultural ideal connected to his "look." His hair is white - non-dyed and natural; his beard has been allowed to grow, and it is also white, and his wrinkles are quite visible. His body seems untreated, rugged, and strong. Additionally, Skjønberg wears an Icelandic sweater and a dark, unbuttoned coat, an outfit arguably connoting "skipper" in the context of Norwegian culture and history. He talks about the importance of sailing with a captain, who has ship steering experience. His dress and words indicate that he is this captain. He is like an embodied rocky shoreline, a tough piece of nature that has taken a lot of bad weather. His body becomes the symbol of something rural, remote and natural. Nature, then, is not only obtainable with/in relationship to nature itself, but can be carried in certain bodies that seem to reject modern developments of "beautifying" products such as hair color, shaving machines, anti-wrinkle remedies, and the latest fashion. This strategy functions to "other" 
nature; like the cowboy, this rugged body is located in the past, and so exoticized, and that legacy is invoked to ensure the delivery and provision of goods and services. Nature is inscribed on the body as a rugged toughness consumers are encouraged to long for. This serves to create a certain brand identity, but more importantly (for this argument) presents nature as something separate from humans' life here and now.

In addition to the rugged body, the odd body also serves to "other" nature, and also recalibrates consumption as the practice which can re-connect Norwegians to nature. This "oddball" body type is a funny-looking, slightly awkward and unglamorous person, which is widespread in Norwegian advertising discourse. A commercial for the dairy products from $Q$ Meieriene provides a good example of such odd bodies. This ad shows two guys, wearing old-fashioned farm-like outfits, discussing a variety of dairy products. A third man, dressed in a white lab coat, shows up on an old bicycle. All characters in this commercial, including the voiceover, speak in a distinct dialect associated with the eastern, rural parts of Norway. Their un-glamorous looks are reinforced as odd by their actions - the farmers discuss the length their products (which is much shorter than their competitors') and conclude that the size has nothing to do with the taste. This way of discussing the quality of dairy products seems offhanded and odd, but that is the very definition of the people in this ad. Contrasted against globalization's generic products and endorsers (such as those used in commercials for fashion and beauty products), the characters are funny-looking, natural and local. With their comic outlook, the characters seem like they are of another world or time. They are "othered" via their old-fashioned style and the remote rural location they speak from. In short, nature is internalized in these down to earth, weird types. Their naturalness is something different and separate from everyday life -representative of the past (as with the rugged body) or connected to the extremely rural and remote. As their naturalness is exoticized or even romanticized, viewers are encouraged to relate to them in caring, but rather condescending and "othering" 
ways. As with the use of the rugged individual, the odd individual also serves to further separate everyday life from nature as this alternative body is still a presentation of nature as separate from everyday life and reifies it as a symbol while validating everyday, material practices of consumption.

In different ways, nature, as it is articulated both on the rugged and the odd body becomes something for the consumer to imagine and long for. Consumers can "take on" nature as a style ultimately functions to recalibrate Norwegians' relationship to nature in these ads, positioning nature as something outside of and separate from the person. In this way, this imaginative pattern also articulates nature as something that can be imaginarily accessed via consumption.

\section{Symbolic Distance and Depoliticization}

Climate change is a serious global challenge that requires real political action and change across the world. Understanding the rhetorical dynamics faced by climate change awareness proponents necessitates attention to nature's symbolism and broader oppositional articulations between the climate change crisis and those proponents. The way we see and understand nature has consequences for how we relate to climate change, as understanding the way we articulate nature and how we position ourselves and our consumer practices in relation to nature play a role in structuring knowledge and social practices of relevance to policies dealing with climate change. Nature articulations in public discourse speaks to local meanings of climate and their relationship to human institutions and behavior more broadly. In short, "communication about the environment matters," and plays "a powerful role in influencing not only how we perceive the environment but also what actions we take" (Cox, 2012, p. 2).

In discussing how nature is articulated in Norwegian advertising discourse and how humans are positioned in relation to nature, I bring attention to four rhetorical patterns in which 
articulation of nature is accomplished, in part: deification, commodification, domination, and internalization. All four patterns speak to an articulation of nature as distant from humans, which works to set up individualized consumptive practices in Norway, in the sense that they all work to encourage individual consumers to imagine the relationship between nature and Norwegianness. When nature is symbolically distanced from Norwegians in this way, it can serve to undermine environmentalism, while at the same time making nature available via individual consumption.

My analyses show that there is a conceptualization of nature as a resource for people, but one that conflates the material and the spiritual. Nature-associated products and services represent a symbolic salvation for urban and culturally inflicted "ills," and "local" looks represent a contrast to a made-up global look. The advertising discourse in an increasingly globalized and consumer focused Norway, then, plays up the central role of nature and emphasizes the negativity of globalization related to such aspects as urbanization and artifice. At the same time, however, consumption is the avenue by which one may resist these "evils" of globalization and reaffirm Norwegians' connection to nature.

Arguably, every commercial, regardless of style or narrative, has the purpose of promoting consumption, an inevitably selfish and exploitive act in that there is an underlying logic of a global market in all aspects of consumption promoting arguments. In this sense, every ad promotes a global consumer culture that challenges Norwegian imagined traditions of humble living and selfless egalitarianism. Despite this, the tensions that surface are not monolithic or even consistent, but rather singularly drawn against globalization, which is pervasive across the board. The presentation of nature in the advertising discourse should also be understood in light of Norway's role in the exploitation of nature through the export of non-renewable resources such as oil and gas, or through fish farming. There is an ambiguity here, but the 
celebration of nature, as well as the symbolic connection between Norwegian people and nature, that the discourse articulates, undermines an alternative conceptualization of Norway (and the Norwegian her/himself) as a greedy exploiter of nature.

My discussion shows how disparate and sometimes conflicting discourses are rhetorically configured and aligned in ways that benefit a global market economy. The calibration of traditional Norwegian values and concepts forces/allows for a seemingly stronger-than-ever local identity, but also an active global consumer culture. In fact, tensions related to values of nature are resolved symbolically by being aligned with individualistic consumer behavior in some way or another. Norwegianness is presented as something available through consumptive practices, which in turn ensures the continued expansion of a global consumer culture. This individualization should be of particular concern to those interested in environmental issues and climate change problems, as research on values in the Norwegian public show that people "holding less individualistic values being more concerned [about climate change] than those holding individualistic values, and those holding egalitarian values being more concerned than those holding less egalitarian values" (Aasen, 2017, p. 225). Furthermore, the findings can be seen as part of a depolitization of nature in contemporary Norway. In fact, I want to suggest that the articulation of nature in these texts play a part in what Swyngedouw (2011) calls the silencing of "ideological and other constitutive social differences," which disavow democratic conflicts by "distilling a common threat to both Nature and Humanity" (p. 268). Such articulations of nature have important implications for Norwegians approach to climate change. Depoliticized discourses and practices are problematized for its reduction of environmental politics to individual moral action and/or technological innovation (Maeseele et al., 2017) and Carvalho et al. (2017) point out how depoliticizing communication constrains people from actively participating "in the articulation and shaping of alternative futures beyond the status-quo" (128). 
The articulation of nature in the Norwegian context has important implications for challenges related to nature and nature use, such as the global issue of climate change. Depoliticized positioning of nature undermines important understandings of how we govern nature, for instance by reducing environmental politics to individualized acts. Larger issues linked to petroleum and fish farming industries then exist along with strong symbolic links between nature and Norwegianness. As such, depoliticization undermines both our ability to deal with real problematic issues regarding developments in nature and the engagement and political framing we need to engage in to have good collective discussions regarding global challenges such as climate change.

Scholars maintain that communication is key to political engagement and shown that some practices open up spaces for citizens to be active participants in the articulation and shaping of alternative sustainable futures while others foreclose them (Carvalho et al., 2017). Being conscious of how we articulate nature and how we position ourselves and our consumer practices in relation to nature is key. While not directly addressing the issue climate change, it is especially relevant in that the articulations play a role in structuring knowledge and social practices of relevance to policies dealing with climate change. In addition to demonstrating the importance of critical cultural analysis in understanding systems of articulation, my analyses highlight the importance of these rhetorical patterns for environmental movements, as well as for environmental communication theory and criticism. I hope that my research will make visible an important aspect of "the continuation of politics-as-usual" (Carvalho et al., 2017, p. 123) and help us understand how we got to where we are and how we may inflect into a different future.

\section{References}

Aasen, M. (2017). The polarization of public concern about climate change in Norway. Climate Policy, 17(2), 213-230. 
Abram, S., \& Lien, M. E. (2011). Performing nature at world's ends. Ethnos, 76(1), 3-18.

Allern, S. (2001). Kildene og mediemakten [The sources and the media power]. Nordicom review: Nordic research on media \& communication, 23(1), 17- 27

Becker, A. E. (2004). New global perspectives on eating disorders. Culture, medicine and psychiatry, 28(4), 433-437.

Berger, J. (1972). Ways of seeing. London: The British Broadcasting Corporation and Penguin Books.

Bookchin, M. (2003). What is social ecology? communalism: International Journal for a Rational Society, 4(January).

Boşnak, M., \& Ceyhan, C. (2003). Riding the horse, writing the cultural myth: The European knight and the American cowboy as equestrian heroes. Alternatives: Turkish Journal of International Relations, 2(1).

Carvalho, A., van Wessel, M., \& Maeseele, P. (2017). Communication practices and political engagement with climate change: a research agenda. Environmental Communication, 11(1), 122-135.

Chapin III, F. S., Peterson, G., Berkes, F., Callaghan, T., Angelstam, P., Apps, M., ... Danell, K. (2004). Resilience and vulnerability of northern regions to social and environmental change. AMBIO: A Journal of the Human Environment, 33(6), 344349.

Corbett, J. B. (2006). Communicating nature: How we create and understand environmental messages: Island Press.

Cox, R. (2012). Environmental communication and the public sphere: Sage publications.

Cruickshank, J. A. (2009). A play for rurality - Modernization versus local autonomy. Journal of Rural Studies, 25, 98-107.

Derrien, M. M., \& Stokowski, P. A. (2017). Discourses of place: environmental interpretation about Vermont forests. Environmental Communication, 11(2), 276287.

Doyle, J. (2013). Mediating climate change: Ashgate Publishing, Ltd.

Foucault, M. (1996). Tingenes orden: En arkeologisk undersøkelse av vitenskapene om mennesket [The order of things: An archaeology of the human sciences]. Oslo: Aventura.

Geisinger, A. (1999). Sustainable development and the domination of nature: Spreading the seed of the Western ideology of nature. Environmental Affairs, 27(43), 43-73.

Gkiouzepas, G., \& Botetzagias, I. (2015). Climate change coverage in Greek newspapers: 2001-2008. Environmental Communication, 1-25.

Gullestad, M. (1989). Small facts and large issues: The anthropology of contemporary Scandinavian society. Annual Review of Anthropology, 18, 71-93.

Gullestad, M. (1991a). Naturen i norsk kultur [Nature in Norwegian culture]. In T. Deichman-Sørensen \& I. Frønes (Eds.), Kulturanalyse [Cultural analysis] (pp. 8197). Oslo: Gyldendal.

Gullestad, M. (1991b). The Scandinavian version of egalitarian individualism. Ethnologia Scandinavica, 21, 3-18.

Gullestad, M. (2002). Det norske sett med nye øyne. In: Oslo: Universitetsforlaget.

Haavind, H. (2000). Kjønn og fortolkende metode. Metodiske muligheter i Kvalitativ Forskning [Gender and Interpretative Method. Methodological Possibilities in Qualitative Research]. Oslo: Gyldendal Akademiske forlag.

Hall, S. (1995). The whites of their eyes: Racist ideologies and the media. In G. Dines \& J. M. Humez (Eds.), Gender, Rase and Class in Media: A Critical Reader (pp. 18-22). London, Thousand Oaks, New Delhi: Sage Publications. 
Hall, S. (1997a). Representation : Cultural representations and signifying practices (Vol. 2). London: SAGE and The Open University.

Hall, S. (1997b). Representation: Cultural representations and signifying practices: Culture, media and identities. . London, Thousand Oaks, New Delhi: Sage.

Halland, L. (1991). Internasjonalisering. En munter-sørgelig historie om norske nordmenn fra Norge [The internationalization. A funny-sad story about Norwegian Norwegians from Norway]. In M. Åstvedt \& H. Andresen (Eds.), Kulturens dekningsbidrag. Om internasjonalisering og kunnskap Gjøvik: J.W. Cappelen Forlag AS.

Hansen, A. (2010). Environment, media and communication: Routledge.

Hansen, A. (2011). Communication, media and environment: Towards reconnecting research on the production, content and social implications of environmental communication. International Communication Gazette, 73(1-2), 7-25.

Hansen, A., \& Machin, D. (2013). Researching Visual Environmental Communication. Environmental Communication, 7(2), 151-168.

Hope, D. S. (2002). Environment as consumer icon in advertising fantasy. In M. Meister \& P. M. Japp (Eds.), Enviropop: Studies in environmental rhetoric and popular culture (pp. 161-174). Westport, London: Greenwood Publishing Group.

Hylland Eriksen, T. (1993). Typisk norsk: Essays om kulturen i Norge [Typically Norwegian: Essays about the Norwegian culture]: C. Huitfeldt Forlag A.S. .

Hylland Eriksen, T. (1996). Norwegians and nature. Retrieved October 16, 2006 www.cyberclip.com/Katrine/NorwayInfo2/Articles/Norw\&Nature.html\#nature

Hylland Eriksen, T. (Writer). (2005). Hva er norsk identitet? Drømmen om Norge [What is Norwegian identity? The dream about Norway] [Televison]. In N. [online] (Producer).

Jameson, F. (1998). Postmodernism and consumer society. In H. Foster (Ed.), The antiAesthetic: Essays on postmodern culture (pp. 127-144). New York: The New Press.

Laclau, E., \& Mouffe, C. (1985). Hegemony and socialist strategy: Towards a radical democratic politics. London: Verso.

Laclau, E., \& Mouffe, C. (1990). Post-Marxism without apologies. In E. Laclau (Ed.), New reflections on the revolution of our time. London: Verso.

Lo, C. (2018). Normative Hierarchy and Pragmatic Egalitarianism in Municipal Policy Development. In Egalitarianism in Scandinavia (pp. 157-178): Springer.

Macnaghten, P., \& Urry, J. (1998). Contested Natures. London: Sage.

Maeseele, P., \& Pepermans, Y. (2017). Climate change communication, media and ideology. In M. Nisbet (Ed.), The Oxford Research Encyclopedia of Climate Change Communication (pp. 1-20). Oxford: Oxford University Press.

Maeseele, P., Raeijmaekers, D., Van der Steen, L., Reul, R., \& Paulussen, S. (2017). In Flanders Fields: De/politicization and democratic debate on a GM potato field trial controversy in news media. Environmental Communication, 11(2), 166-183.

Neuman, R., Just, M. R., \& Crigler, A. N. (1992). Common knowledge. News and the construction of political meaning. Chicago, London: The University of Chicago Press.

Neumann, I. B. (2001). Norge - en kritikk: Begrepsmakt i Europa-debatten [Norway - a critique: Power of terms in the debate on Europe]. Oslo: Pax Forlag A/S.

Norway, S. (2017). This is Norway 2017.

Ott, B., \& Walter, C. (2000). Intertextuality: Interpretive practice and textual strategy. Critical Studies in Media Communication, 17(4), 429-446. 
Pearce, W., Grundmann, R., Hulme, M., Raman, S., Hadley Kershaw, E., \& Tsouvalis, J. (2017). Beyond Counting Climate Consensus. Environmental Communication, 1-8.

Pepermans, Y., \& Maeseele, P. (2014). Democratic debate and mediated discourses on climate change: From consensus to de/politicization. Environmental Communication, 8(2), 216-232.

Rogers, R. A. (2008). Beasts, burgers, and hummers: Meat and the crisis of masculinity in contemporary television advertisements. Environmental Communication, 2(3), 281-301.

Rybråten, S. (2013). "This is not a wilderness. This is where we live. "Enacting nature in Unjárga-Nesseby, Northern Norway. (Ph.D.), University of Oslo,

Sakslind, R., \& Skarpenes, O. (2014). Morality and the middle class: The European pattern and the Norwegian singularity. Journal of Social History, 48(2), 313-340.

Schmidt, A., Ivanova, A., \& Schäfer, M. S. (2013). Media attention for climate change around the world: A comparative analysis of newspaper coverage in 27 countries. Global Environmental Change, 23(5), 1233-1248.

Serazio, M., \& Szarek, W. (2012). The art of producing consumers: A critical textual analysis of post-communist Polish advertising. European Journal of Cultural Studies, 15(6), 753-768.

Skår, M., \& Krogh, E. (2010). Opplevelse av natur og tid i hverdagslivet [Experiencing nature and time in everyday life]. Tidsskrift for kulturforskning, 9(3).

Slack, J. D. (1996). The theory and method of articulation in cultural studies. In D. Morley \& K.-H. Chen (Eds.), Stuart Hall: Critical dialogues in cultural studies (pp. 112127). London, New York: Routledge.

Sørenssen, B. (2001). Radical romanticism in Scandinavian documentary: The Norwegian nature meme in For harde livet. Film History, 13(1), 50-57.

Stoddart, M. C., Tindall, D. B., Smith, J., \& Haluza-Delay, R. (2017). Media Access and Political Efficacy in the Eco-politics of Climate Change: Canadian National News and Mediated Policy Networks. Environmental Communication, 11(3), 386-400.

Sundsvold, B. (2010). Stedets herligheter-amenities of place: eider down harvesting through changing times. Acta Borealia, 27(1), 91-115.

Swyngedouw, E. (2011). Depoliticized Environments: The End of Nature, Climate Change and the Post-Political Condition. Royal Institute of Philosophy Supplement, 69, 253-274.

Swyngedouw, E. (2013). The Non-political Politics of Climate Change. ACME: An International E-Journal for Critical Geographies, 12(1), 1-8.

Vespestad, M. K. (2010). Promoting Norway Abroad: A Content Analysis of Photographic Messages of Nature-Based Tourism Experiences. Tourism Culture \& Communication, 10(2), 159-174. doi:10.3727/109830410x12815527582945

Ween, G. B., \& Abram, S. (2012). The Norwegian Trekking Association: Trekking as Constituting the Nation. Landscape Research, 37(2), 155-171.

Wiborg, A. (2003). Den flertydige lokale tilhørighet [The multifaceted local belonging]. In T. Thuen (Ed.), Sted og tilhørighet [Place and belonging] (pp. 127-152): Høyskoleforlaget AS - Norwegian Academic Press.

Williams, D. (2001). The Social Construction of Arctic Wilderness: Place Meanings, Value Pluralism, and Globalization. Paper presented at the Wilderness in the Circumpolar North: Searching for Compatibility in Ecological, Traditional, and Ecotourism, Values, University of Alaska, Anchorage.

Williams, R. (1983). Keywords: A vocabulary of culture and society (2nd ed.). New York: Oxford University Press. 
Williams, R. (1993). Advertising: The magic system. In S. During (Ed.), The cultural studies reader. London, New York: Routledge.

Witoszek, N. (1998). Fra Edda til økofilosofi [From Edda to eco-philosophy]. Oslo: Pax.

\footnotetext{
'The word "Telemark" invokes specific Norwegian connotations (such as the "telemark bunad," "telemark rosemaling," and "telemark skiing") tied to items and practices of historic and nationalistic significance.
} 